\title{
METHODOLOGICAL APPROACHES TO ASSESS PASSION FRUIT RESISTANCE (Passiflora spp.) TO PASSIONFRUIT WOODINESS DISEASE
}

\author{
ASPECTOS METODOLÓGICOS PARA AVALIAÇÃO DA RESISTÊNCIA DO \\ MARACUJAZEIRO (Passiflora spp.) À VIROSE DO ENDURECIMENTO DOS \\ FRUTOS
}

\author{
Zanon Santana GONÇALVES ${ }^{1}$; Onildo Nunes de JESUS ${ }^{2}$; \\ Carlos Bernard Moreno CERQUEIRA-SILVA ${ }^{3}$; Rafael Parreira DINIZ ${ }^{2}$; \\ Taliane Leila SOARES ${ }^{2}$; Eder Jorge de OLIVEIRA ${ }^{2}$ \\ 1. Universidade Federal do Recôncavo da Bahia - URFB, Centro de Ciências Agrárias, Ambientais e Biológicas, Cruz das Almas, BA, \\ Brasil; 2. Embrapa Mandioca e Fruticultura, Cruz das Almas, BA, Brasil; 3. Universidade Estadual do Sudoeste da Bahia - UESB, \\ Itapetinga, BA, Brasil
}

\begin{abstract}
The passion fruit woodiness disease, induced by Cowpea aphid borne mosaic virus (CABMV), is considered the most economically important factor limiting passion fruit production in many countries. This study aimed to assess the progression of symptoms caused by CABMV in different Passiflora species. Eighty genotypes belonging 12 species were evaluated in experiments carried out in a completely randomized block design with treatments arranged in a factorial scheme ( 80 genotypes x 7 evaluation intervals) considering each inoculated plant as a repetition. The disease severity was estimated by the disease index (DI). The evaluations were performed at 20, 27, 34, 41, 48, 55 and 62 days after inoculation (DAI). The average DI values were used to describe the disease progress at each evaluation interval. The shortest time from evaluation to stabilization of CABMV progress was considered to cluster the genotypes by the ScottKnott test ( $\mathrm{p} \leq 0.05)$ and to classify the genotypes as resistant $(\mathrm{R})$, moderately resistant (MR), moderately susceptible (MS), susceptible (S) or highly susceptible (HS). The mean severity gradually increased in the intervals from 20 to 55 DAI and reached a maximum at 62 DAI. The five classes (R, MR, MS, S and HS) contained about 19, 24, 36, 10 and $11 \%$ of the germplasm accessions, respectively. The disease temporal progress was quite variable within and among groups, although no difference in DI was observed in the genotypes after 55 DAI, indicating genotype symptom stabilization at this time, regardless of the genotype resistance level.
\end{abstract}

KEYWORDS: Passifloraceae. Temporal dynamics. Disease progress. Viruses.

\section{INTRODUCTION}

The passionfruit (Passiflora edulis Sims f. flavicarpa Degener.) is one of the most important fruits in Brazil, which accounts for over $70 \%$ of world production (FERREIRA et al. 2010; MELO et al. 2015). The increase in planted area has exposed the plant to several diseases, most of viral etiology (GARCÊZ et al. 2015), which are regarded as the most severe and cause major economic damage to passionfruit crops (CERQUEIRA-SILVA et al. 2014; MELO et al. 2015).

The Cowpea aphid-borne mosaic virus (CABMV), family Potyviridae, genus Potyvirus, is considered the most important virus species that infect cowpea in Northeastern Brazil (LIMA et al., 2015). According to Adams et al. (2012), CABMV is related but from the bean common mosaic virus (BCMV) subgroup of potyviruses, which also includes Passionfruit Woodiness Virus (PWV) and East Asian Passiflora virus (EAPV). In passionfruit the woodiness disease induced by CABMV is widespread in Brazil (BARROS et al. 2011; NICOLINI et al. 2012; SANTOS et al. 2015;
FREITAS et al. 2015; MELO et al. 2015). CABMV causes serious quantitative and qualitative damages in passionfruit production, such as reduction in plants development; mosaic, blistering and distortion on leaves; fruit woodiness; reduction in juice yield; and shorter lifespan of orchards (OLIVEIRA et al. 2013; CORREA et al., 2015).

CABMV is transmitted by aphid vectors in a non-circulative, non-persistent manner, (MACIEL et al., 2009; BRAGARD et al. 2013). The strategies adopted to date have not been effective to control or eradicate CABMV in commercial passionfruit orchards (FISCHER; RESENDE, 2008; CERQUEIRA-SILVA et al. 2014), which has limited the expansion of the crop in Brazil (OLIVEIRA et al. 2013; CERQUEIRA-SILVA et al. 2014; CORREA et al. 2015).

Although passionfruit breeding programs have developed varieties with high yield and fruits with desirable characteristics, it has not yet been possible to develop a variety of $P$. edulis $\mathrm{f}$. flavicarpa Deg. with strong resistance to CABMV. The exploitation of genetic variability present in germplasm banks is important because it is possible 
to find sources of genetic resistance to CABMV. Thus, passionfruit breeding programs could use these sources to transfer resistance genes from wild to commercial species through interspecific hybridization (SANTOS et al. 2015).

The identification of resistant accessions from germplasm banks, varieties that are already available in the market, and even wild specimens, through artificial inoculations in controlled conditions constitutes an important tool for rapid phenotyping of Passiflora germplasm in the search for sources of resistance. In this sense, the adoption of methods that promote the identification of Passiflora resistance level in plants from segregating populations or germplasm banks quickly and efficiently is essential for the development of resistant varieties. In addition to the methodological approaches for selection, the temporal analysis of the symptoms caused by CABMV can reveal important epidemiological events, such as the time required for disease onset, variation in its intensity and period of maximum severity after inoculation. Thus, the present study aimed to evaluate the progress of the symptoms caused by CABMV in different species of Passiflora in order to define accurate strategies to search for sources of CABMV resistance.

\section{MATERIAL AND METHODS}

The study was conducted at the experimental farm of the Embrapa Cassava and Fruits research unit, located in Cruz das Almas, Bahia, Brazil, (1240’39” S, 3906’23” W, 226 m altitude). We evaluated 80 genotypes of passionfruit (Passiflora spp.) from 12 different species, which consisted of 61 genotypes of $P$. edulis Sims $f$. flavicarpa Deg., one of $P$. alata Curtis., one of $P$. malacophylla Mast., four of $P$. cincinnata Mast., one of P. setacea DC., one of $P$. foetida L., one of $P$. gibertii N.E Brown., one of $P$. ligularis Juss., one of $P$. maliformis L., two of $P$. morifolia Mast., five of $P$. suberosa L. and one of $P$. subrotunda Mast. (Table 1).

Table 1. Wild, commercial and hybrid passionfruit genotypes (Passiflora spp.) used to evaluate the severity of Cowpea aphid borne mosaic virus (CABMV).

\begin{tabular}{|c|c|c|c|c|c|c|c|}
\hline$\overline{\mathrm{N}^{\mathrm{o}}}$ & Code & Species $^{1}$ & Origin & $\mathrm{N}^{\mathrm{o}}$ & Code & Species $^{1}$ & Origin \\
\hline$\overline{1}$ & H09-14 & P. e.fla & $\mathrm{BA}$ & 41 & BGP189 x BGP345 & P. e.fla & $\mathrm{BA}$ \\
\hline 2 & HFOP-09 & P. e. fla & $\mathrm{BA}$ & 42 & BGP424 & P. e.fla & $\mathrm{BA}$ \\
\hline 3 & H09-02 & P. e.fla & $\mathrm{BA}$ & 43 & BGP425 & P. e.fla & $\mathrm{BA}$ \\
\hline 4 & BRS Gigante Amarelo & P. e.fla & $\mathrm{BA}$ & 44 & BGP325 & P. e.fla & SP \\
\hline 5 & BRS Rubi do Cerrado & P. e.fla & $\mathrm{BA}$ & 45 & BGP334 & P. e.fla & $\mathrm{BA}$ \\
\hline 6 & HFOP-08 & P. e.fla & $\mathrm{BA}$ & 46 & BGP188 & P. e.fla & SP \\
\hline 7 & BGP396 & P. e.fla & $\mathrm{BA}$ & 47 & BGP400 & P. e.fla & $\mathrm{BA}$ \\
\hline 8 & BRS Sol do Cerrado & P. e.fla & $\mathrm{BA}$ & 48 & BGP177 & P. e.fla & $\mathrm{BA}$ \\
\hline 9 & FB300 & P. e.fla & $\mathrm{BA}$ & 49 & BGP189 & P. e.fla & SP \\
\hline 10 & BGP393 & P. alata & $\mathrm{CE}$ & 50 & BGP327 & P. e. fla & SP \\
\hline 11 & BGP415 & P. mor & $\mathrm{SP}$ & 51 & BGP190 & P. e. fla & $\mathrm{SP}$ \\
\hline 12 & BGP107 & P. mor & SP & 52 & BGP330 & P. e. fla & $\mathrm{BA}$ \\
\hline 13 & BGP379 & P. mali & $\mathrm{BA}$ & 53 & BGP223 & P. e. fla & BA \\
\hline 14 & BGP134 & P. sube & $\mathrm{BA}$ & 54 & BGP205 & P. e. fla & SP \\
\hline 15 & BGP143 & P. sube & $\mathrm{SP}$ & 55 & BGP328 & P. e. fla & $\mathrm{DF}$ \\
\hline 16 & BGP014 & P. sube & SP & 56 & BGP185 & P. e.fla & SP \\
\hline 17 & BGP112 & P. sube & - & 57 & BGP418 & P. e. fla & $\mathrm{BA}$ \\
\hline 18 & BGP152 & P. sube & SP & 58 & BGP238 & P. set & BA \\
\hline 19 & BGP160 & P. ligu & BA & 50 & BGP413 & P. cin & SP \\
\hline 20 & BGP395 & P. foe & MT & 60 & BGP077 & P. cin & $\mathrm{BA}$ \\
\hline 21 & BGP394 & P. subr & $\mathrm{BA}$ & 61 & BGP414 & P. gib & SP \\
\hline 22 & H09-10 & P. e. fla & $\mathrm{BA}$ & 62 & BGP031 & P. e.fla & $\mathrm{BA}$ \\
\hline 23 & H09-07 & P. e.fla & $\mathrm{BA}$ & 63 & BGP032 & P. e. fla & PR \\
\hline 24 & H09-30 & P. e. fla & $\mathrm{BA}$ & 64 & BGP037 & P. e. fla & PA \\
\hline 25 & HFOP-05 & P. e. fla & BA & 65 & BGP051 & P. e. fla & MG \\
\hline 26 & RC2-45-P14x224 & H. inter & $\mathrm{BA}$ & 66 & BGP123 & P. e. fla & $\mathrm{SP}$ \\
\hline 27 & RC2-57-P8x224 & H. inter & $\mathrm{BA}$ & 67 & BGP224 & P. e.fla & $\mathrm{BA}$ \\
\hline 28 & RC2-44-P8x222 & H. inter & $\mathrm{BA}$ & 68 & BGP227 & P. e. fla & SP \\
\hline 29 & RC2-45-P18PA & H. inter & $\mathrm{BA}$ & 69 & BGP345 & P. e.fla & $\mathrm{BA}$ \\
\hline 30 & RC2-45-P8x222 & H. inter & $\mathrm{BA}$ & 70 & BGP222 & P. e.fla & $\mathrm{BA}$ \\
\hline 31 & RC2-44-P3x224 & H. inter & $\mathrm{BA}$ & 71 & BGP005 & P. e.fla & SP \\
\hline 32 & $\mathrm{RC} 2-45-\mathrm{P} 10 \times 223$ & H. inter & $\mathrm{BA}$ & 72 & BGP064 & P. e.fla & $\mathrm{BA}$ \\
\hline
\end{tabular}




\begin{tabular}{|c|c|c|c|c|c|c|}
\hline 33 & RC2-45-P14x223 & H. inter & $\mathrm{BA}$ & 73 & BGP324 & P. e. fla \\
\hline 34 & RC2-44-P8x185 & H. inter & $\mathrm{BA}$ & 74 & BGP351 & P. e. fla \\
\hline 35 & BGP165 & P. e. fla & $\mathrm{BA}$ & 75 & BGP341 & P. e.fla \\
\hline 36 & BGP170 & P. mala & - & 76 & BGP210 & P. e. fla \\
\hline 37 & BGP128 & P. e. fla & SP & 77 & BGP221 & P. e. fla \\
\hline 38 & Seleção-2 & P. e. fla & $\mathrm{BA}$ & 78 & BGP061 & P. e. fla \\
\hline 39 & BGP428 & P. e. fla & $\mathrm{BA}$ & 79 & BGP200 & P. cin \\
\hline 40 & Seleção-1 & P. e. fla & $\mathrm{BA}$ & 80 & BGP268 & P. cin \\
\hline
\end{tabular}

${ }^{1}$ P. e. fla = Passiflora edulis flavicarpa; P. alata = P. alata; P. mor = P. morifolia; P. mali = P. maliformis; P. sube $=$ P. suberosa; P. ligu $=P$. ligularis; $P$. foe $=P$. foetida $; P$. subr $=P$. subrotunda $; \mathrm{H}$. inter $=$ Hibrido interespecífico; $P$. mala $=P$. malacophylla $; P$. set $=$ $P$. setacea $;$. $\operatorname{cin}=P$. cincinnata $; P$. gib $=P$. gibertii $. \mathrm{BA}=$ Bahia; $\mathrm{CE}=$ Ceará; $\mathrm{SP}=\mathrm{São}$ Paulo; $\mathrm{MT}=\mathrm{Mato}$ Grosso; $\mathrm{DF}=\mathrm{Distrito}$ Federal; $\mathrm{PR}=$ Paraná; Pará; $\mathrm{MG}=$ Minas Gerais.

Approximately 20 seeds of each genotype were pre-soaked in $20 \mathrm{~mL}$ of water for 60 minutes. Then the seeds were germinated in polyethylene pots (volume of $1.0 \mathrm{~L}$ ) containing a mixture of coconut fiber $(120 \mathrm{~L})$, Vivatto ${ }^{\circledR}(40.0 \mathrm{~L})(3: 2)$, plus $40.0 \mathrm{~g}$ of Osmocote for every $10.0 \mathrm{~L}$ of substrate. After germination, 10 vigorous plants of each genotype were selected to compose the test. The greenhouse was maintained at a controlled temperature of about $28 \pm 2{ }^{\circ} \mathrm{C}$ and relative humidity $(\mathrm{RH})$ of $45 \%$ throughout the test.

The isolate used for the artificial inoculations was originally obtained from $P$. edulis plants kept in a greenhouse with CABMV symptoms, after diagnostic tests by Plate Trapped Antigen-ELISA (MOWAT; DAWSON, 1987). For the inoculations, an extract was prepared from leaves of symptomatic plants, macerating the ratio of $1.0 \mathrm{~g}$ of tissue to $10 \mathrm{ml}$ of a buffer solution $(0.1$ $\mathrm{M}$ potassium phosphate and sodium sulfite $0.1 \mathrm{M}$, pH 7.0) (CERQUEIRA-SILVA et al., 2008). Then a small amount of celite $(1.0 \mathrm{~g})$ was used as an abrasive to cause injury to the foliar surface. Viral particles were inoculated on the plants by rubbing the adaxial leaf surface with a finger moistened in the extract only once to standardize the inoculum pressure.

From the 10 plants selected of each species, eight were inoculated mechanically with an aggressive CABMV isolate, and the other two were inoculated only with the buffer and celite (negative control). The inoculation was performed on healthy plants at the seven- to nine-leaf stage, approximately 100 days after planting. The inoculations were performed twice at four-day intervals, with two leaves per plant inoculated at each inoculation, always using basal leaves (with the exception of cotyledons). Ten minutes after inoculation, the inoculated leaves were washed to remove the excess celite.

The characterization of the reaction of passionfruit genotypes to CABMV infection was performed based on visual symptoms of the disease.
All leaves had been numbered as they emerged, and the evaluations were carried out from the eighth fully developed leaf. The first assessment was carried out 20 days after the first inoculation (DAI), and the others were carried out at seven-day intervals until the seventh evaluation, at 62 DAI.

The evaluation of disease symptoms was based on a scoring scale ranging from 1 to 4 , where $1=$ no mosaic symptoms, 2 = light mosaic without leaf distortion, $3=$ severe mosaic without leaf distortion, and $4=$ severe mosaic, bubbles and leaf distortion, as proposed by NOVAES; REZENDE (2003) (Figure 1). This scoring scale made it possible to assess the absence or presence of different levels of leaf symptoms of the disease. The identity of the CABMV isolate used for inoculating the plants was previously confirmed by RT-PCR using specific primers of the cylindrical insertion region of the virus to amplify a fragment of $700 \mathrm{bp}$ (HA et al. 2008). All inoculated and asymptomatic plants as well as the negative control (uninoculated) were evaluated by RT-PCR to validate the presence of CABMV.

The disease severity was quantified using the disease index (DI) proposed by McKinney (1923). This index is estimated based on the weight of the infection scoring scale by applying the following formula:

$$
D I(\%)=\frac{\Sigma(\text { GS } \times \text { L) }}{(\text { TNL } \times \text { HGS })} \times 100
$$

where:

$\mathrm{L}=$ number of leaves appearing at each grade of the scale;

$\mathrm{TNL}=$ total number of leaves;

HGS $=$ highest grade of the scale.

Analysis of variance was performed considering the completely randomized block design with treatments arranged in a factorial scheme (80 genotypes x 7 evaluation times). Each inoculated plant was considered one repetition (eight plants in total). 

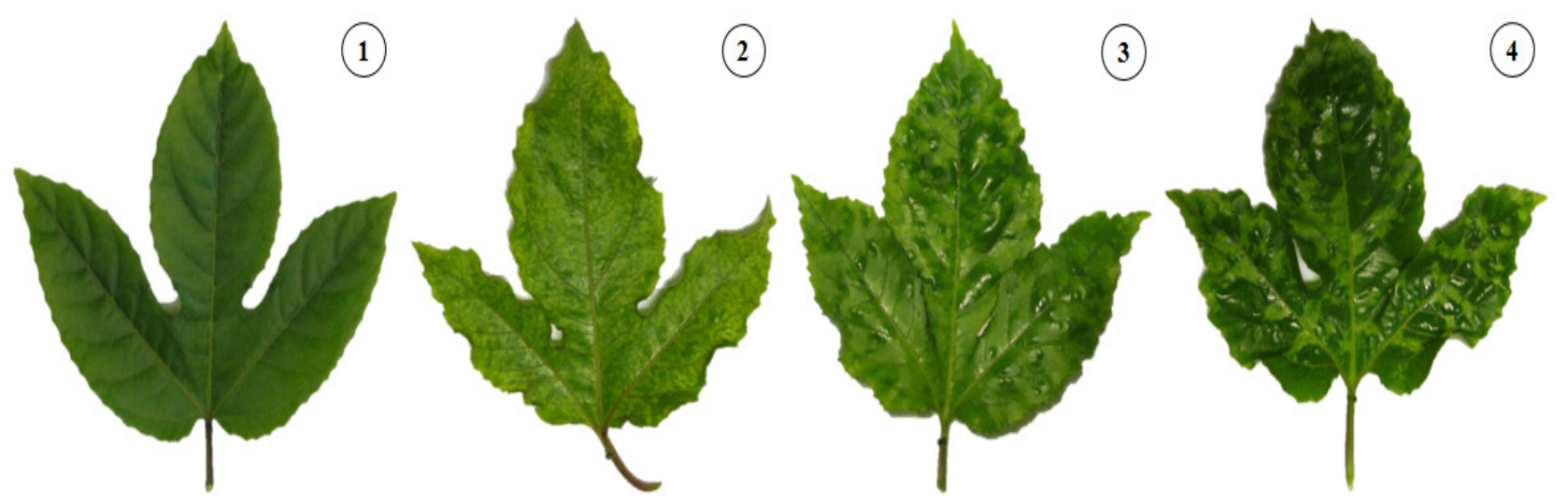

Figure 1. Yellow passionfruit leaves (Passiflora edulis Sims f. flavicarpa) with characteristic symptoms of passionfruit woodiness disease (Cowpea aphid borne mosaic virus - CABMV). Scale from 1-4 (NOVAES; RESENDE, 2003).

The average DI values for each evaluation time and genotype were grouped by the Scott-Knott test $(\mathrm{p} \leq 0.05)$. DI values from asymptomatic plants of Passiflora edulis f. flavicarpa were not used in the analysis. Means of DI for all genotypes were plotted in a logarithmic curve to determine the disease progress curve (DPC).

Based on the analysis of the data of CABMV symptom progress, the minimum time to stabilize the disease symptoms in the Passiflora species evaluated was established. This minimum time was used to group the genotypes by the ScottKnott test $(p \leq 0.05)$. Based on this grouping, the genotypes were classified as resistant (R; DI ranging from 0.00 to $8.61 \%$ ), moderately resistant (MR; DI ranging from 17.34 to $27.19 \%$ ), moderately susceptible (MS; DI ranging from 29.06 to $43.77 \%$ ), susceptible (S; DI ranging from 45.58 to $62.70 \%$ ) or highly susceptible (HS; DI ranging from 69.51 to $90.50 \%$ ). Based on this classification or on the average cluster, regression curves were prepared with the logarithmic model, the coefficient of determination $\left(\mathrm{R}^{2}\right)$ was calculated and the equation was adjusted for each group. All analyses were performed using the "agricolae" package implemented in the $\mathrm{R}$ program ( $\mathrm{R}$ DEVELOPMENT CORE TEAM, 2015).

\section{RESULTS AND DISCUSSION}

The analysis of variance revealed a significant effect for most of the sources of variation studied - blocks, genotypes and days after inoculation (DAI) - relative to the disease index, with the exception of the genotype $x$ DAI interaction (Table 2).

The significant differences between the means of the DI and the DPC demonstrated the existence of genetic variability among genotypes of Passiflora assessed for severity of CABMV (Table 2; Figure 2). Similarly, other authors have also verified the existence of genetic variability in reaction to CABMV under field conditions (CERQUEIRA-SILVA et al. 2008; OLIVEIRA et al. 2013).

Table 2. Summary of the analysis of variance for disease index (DI\%) of Passiflora genotypes evaluated on different days after artificial inoculation (DAI) with Cowpea aphid borne mosaic virus (CABMV).

\begin{tabular}{llll}
\hline Source of variation & Degree of freedom & Mean square & F Test \\
\hline Blocks & 7 & 809.14 & $8.55^{* *}$ \\
Genotypes & 79 & 12939.51 & $136.70^{* *}$ \\
DAI & 6 & 26254.67 & $277.36^{* *}$ \\
Genotypes x DAI & 474 & 96.43 & $1.02^{\text {ns }}$ \\
Error & 3290 & 94.66 & \\
\hline CV $(\%)$ & 38.8 & & \\
\hline
\end{tabular}

${ }^{* *}$ highly significant by F-test $(\mathrm{p} \leq 0.01) .{ }^{\mathrm{ns}}$ not significant by F-test $(\mathrm{p} \leq 0.05)$. 


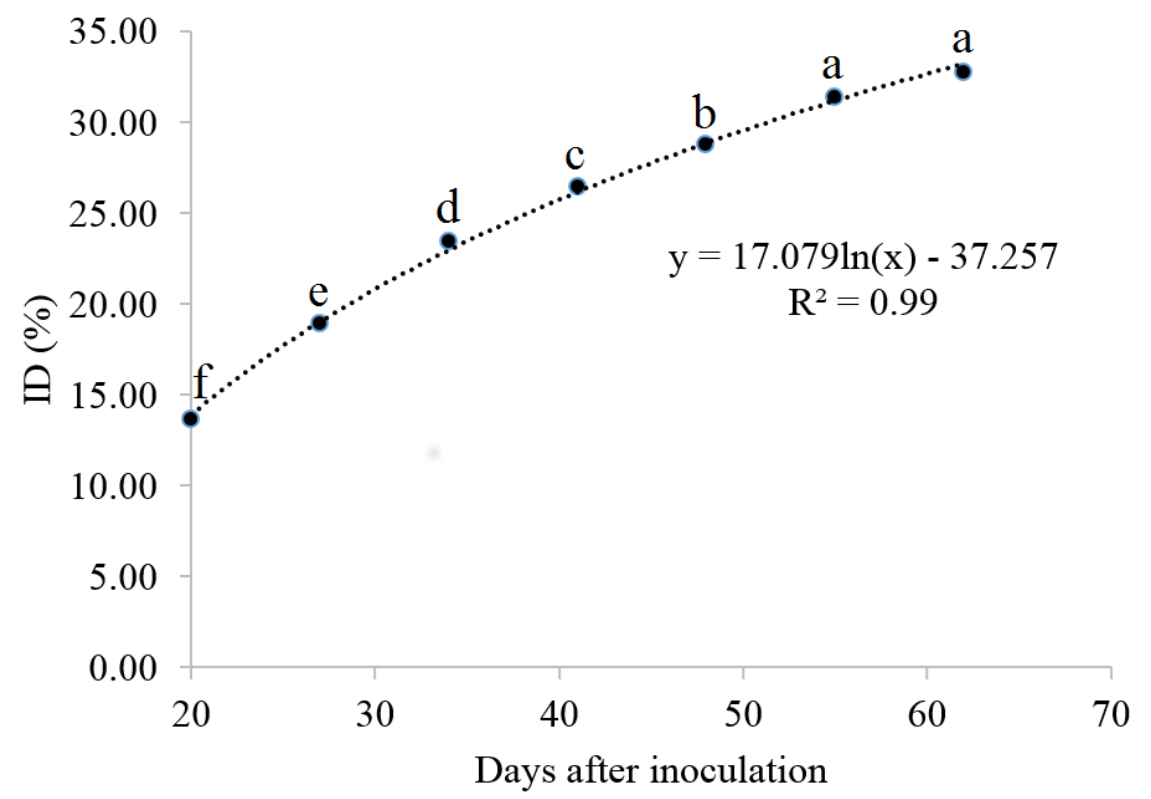

Figure 2. Disease progress curve (DPC) obtained by the average disease Index (DI\%) in passionfruit plants infected with Cowpea aphid borne mosaic virus (CABMV) at different days after inoculation (DAI). Means followed by the same letter of each DAI belong to the same group by the Scott-Knott test $(\mathrm{p} \leq 0.05)$.

In the present study, we observed 18 accessions of $P$. edulis f. flavicarpa with asymptomatic plants to CABMV. These accessions were discarded from the analyses, since they were classified as susceptible with a high DI, and therefore with a tendency to be escape plants. On the other hand, although immunity of plants within the different Passiflora accessions is unlikely, this possibility should not be discarded in future research, since virus-associated events, such as virion components or virus-encoded proteins, could be perceived by putative cell surface plant pattern recognition receptors (PRRs) or cytosolic nucleotide-binding leucine-rich repeat (NB-LRR) to trigger analogous effector-triggered immune or susceptible responses in plants (MANDADI; SCHOLTHOF, 2013). However, the DI values from asymptomatic plants within susceptible accessions were discarded since we could not confirm their immune response.

The range of values of the disease index as a function of genotype $x$ DAI interaction estimated by the logarithmic model showed a good fit in the model proposed, with a coefficient of determination $\left(\mathrm{R}^{2}\right)$ of $99.0 \%$ (Figure 2). Plants started showing CABMV symptoms at 20 DAI, with the disease severity gradually increasing over time until the maximum severity was observed at 62 DAI, although no significant difference was observed from 55 DAI to 62 DAI (Figure 2). The relatively slow progress of CABMV infection at the initial evaluation time (20 DAI) may be related to the low concentration of the pathogen in the plant, as well as the time required for visual expression of symptoms. In the present study, we observed that the severity of the pathogen increased with the development of the plant after inoculation. Some authors have reported that the high cell reproduction rate can contribute to increased viral replication as well as virus spread/movement in plants through vascular tissues, causing the disease to become systemic (BOON et al., 2010). Furthermore, viruses do not have an autonomous system of replication, and it is therefore necessary for replication to occur in host cells (CHRISTENSEN et al., 2009; NETHERTON; WILEMAN, 2011).

Recent studies have found that in the initial infection by the pathogen, there is no visual manifestation of the first steps for viral establishment in the host because the whole process is occurring at the cellular level (DOLNIK et al. 2015). Still, according to these authors the initial moment of infection cannot be determined only from the visual symptoms of the disease because the expression is related to the development of mechanisms of the affected organ, which has little relationship to the moment of infection. The exact incubation period of CABMV is not known. However, changes in certain environmental factors, mainly in climate factors such as light, relative 
humidity and temperature, as well as 'seedlings' nutritional status and age difference among plants, can influence the expression of disease symptoms (VIDA et al. 2004; LEÃO et al. 2006; PINTO et al. 2008). It is important to consider that the progress of the disease (Figure 3 ) refers to the average of all
Passiflora genotypes evaluated. However, the level of CABMV reaction is genotype-dependent that is, depending on the genotype or species of passionfruit under evaluation, the symptoms of the disease progress are variable, according to the existence of resistance mechanisms inherent to each genotype.

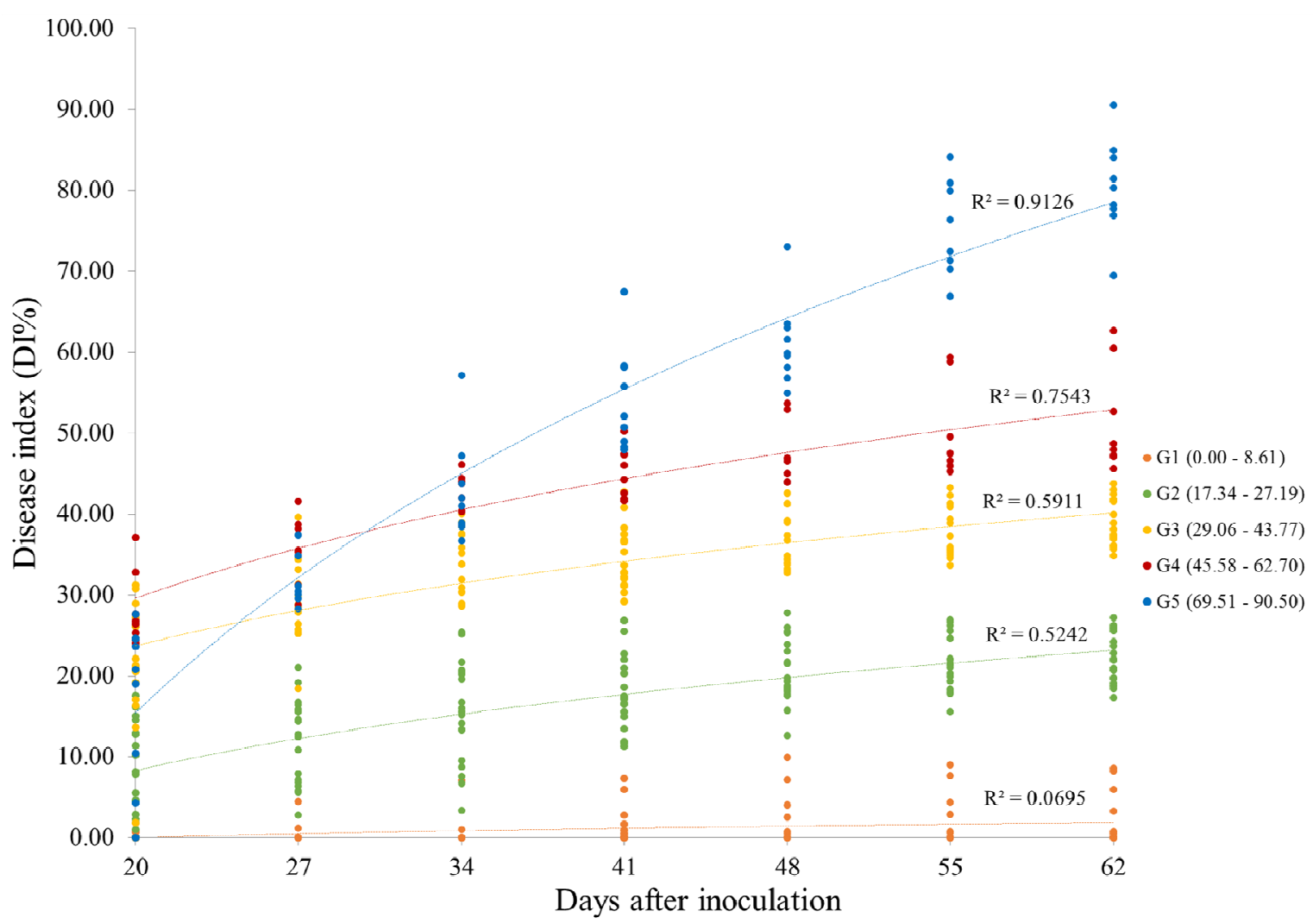

Figure 3. Logarithmic regression of disease index (DI\%) in five groups of passionfruit infected with Cowpea aphid borne mosaic virus (CABMV), classified according to the level of resistance based on average Scott-Knott test ( $\mathrm{p} \leq 0.05)$. G1 = resistant, G2 = moderately resistant, $\mathrm{G} 3=$ moderately susceptible, $\mathrm{G} 4=$ susceptible and G5 = highly susceptible. The values in parentheses represent the amplitude of the disease index (DI\%) of the genotypes that make up each group.

The results indicated stabilization of CABMV symptoms on leaves at $55 \mathrm{DAI}$, indicating that the reaction of passionfruit genotypes regarding resistance or susceptibility can be determined in this period. On the other hand, VIANA et al. (2014) evaluated the CABMV resistance in sour passionfruit genotypes until 60 DAI under greenhouse conditions, and reported that the highest severity values were found at 30 DAI. The maximum severity observed at day 30 could have been due to the use of species that were more susceptible to CABMV, which therefore resulted in severe symptoms in an early stage of plant development. SANTOS et al. (2015) assessed sour passionfruit genotypes' reaction to CABMV under field conditions and reported that symptom expression was influenced by environmental conditions. They also suggested that screening in the field should be performed both in environments that are favorable and in those that are unfavorable to development of the disease, in order to verify the stability of passionfruit genotypes to CABMV reaction. However, artificial inoculation under controlled conditions has the important advantage of allowing the selection of genotypes in a short time frame by screening a larger number of accessions during the year. Furthermore, there is less environmental influence on the expression of symptoms of viral infection.

The curve of disease progress obtained by plotting the disease index values (severity \%) versus time for each group's resistance to CABMV was expressed by the logarithmic model (Figure 3), and five classes of CABMV resistance were observed. The lowest severity was observed in group 1 (G1), which had DI values from 0.00 to $8.61 \%$ and was 
considered resistant. This group included 15 passionfruit genotypes (BGP014, BGP112, BGP134, BGP143, BGP152, BGP170, BGP077, BGP200, BGP238, BGP268, BGP413, BGP414, BGP188, H0930 and Selection2), belonging to six different species of Passiflora: P. suberosa, $P$. malacophylla, $P$. cincinnata, $P$. setacea, $P$. gibertii and $P$. edulis f. flavicarpa. In $\mathrm{G} 1$, there was practically no disease progress by 27 DAI for the genotypes, except for some individuals of $P$. cincinnata (BGP200 and BGP268), P. gibertii (BGP414) and P. edulis (BGP188, H0930 and Selection2), which showed some leaves with mild symptoms (DI values of $0.78,8.64,3.27,0.56,6.03$ and $8.61 \%$ ), which contributed to slow average progress of the virus in this group. Group 2 (G2) consisted of 19 genotypes with a DIs ranging from $17.34 \%$ to $27.19 \%$, classified as moderately resistant. The highest values of initial severity were observed in group 3 (29 genotypes) and group 4 (8 genotypes), so these groups were classified as moderately susceptible (DI from 29.06 to $43.77 \%$ ) and susceptible (DI from $45.58 \%$ to $62.70 \%$ ), respectively.
CABMV symptoms of G5 evolved much faster compared to the other groups (Figure 3). DI values in this group ranged from 69.51 to $90.50 \%$, and it includes genotypes with high susceptibility to CABMV. The high severity observed in G5 can be explained by the fact that it contains cultivars and hybrids of sour passionfruit (BRS Sol do Cerrado, FB300, BRS Rubi do Cerrado, BRS Gigante Amarelo, BGP160, HFOP-08, H0914 and HFOP09).

The difference in the severity of CABMV among groups can be established based on the average DI for each group by the evaluation time (Table 3). At 20 DAI, the DIs of the moderately susceptible (MS) group (G3) and the highly susceptible (HS) group (G5) were similar, indicating they had almost the same initial reaction to CABMV. From 27 DAI, however, we observed different behaviors among the groups. The highest initial severity occurred in the susceptible group (G4). However, at 27 and 34 DAI there was no difference in reaction to CABMV for the $\mathrm{S}$ and HS groups, and only from 41 DAI did the HS groups show the highest severity of CABMV (Table 3 ).

Table 3. Average disease index of Cowpea aphid borne mosaic virus (CABMV) on the basis of evaluation days after inoculation and resistance groups: $\mathrm{R}$ - resistant; MR - moderately resistant; MS - moderately susceptible; $\mathrm{S}$ - susceptible; HS - highly susceptible.

\begin{tabular}{llllll}
\hline $\begin{array}{l}\text { Days } \\
\text { inoculation }\end{array}$ & after & Class/Groups & & & \\
\cline { 2 - 6 } & R (G1) & MR $(\mathrm{G} 2)$ & MS $(\mathrm{G} 3)$ & $\mathrm{S}(\mathrm{G} 4)$ & HS $(\mathrm{G} 5)$ \\
\hline 20 & $0.17 \mathrm{aA}$ & $8.01 \mathrm{aB}$ & $19.10 \mathrm{aC}$ & $28.09 \mathrm{aD}$ & $17.23 \mathrm{aC}$ \\
27 & $0.37 \mathrm{aA}$ & $12.03 \mathrm{bB}$ & $24.22 \mathrm{bC}$ & $35.61 \mathrm{bD}$ & $32.66 \mathrm{bD}$ \\
34 & $0.54 \mathrm{aA}$ & $15.47 \mathrm{cB}$ & $29.12 \mathrm{bC}$ & $43.11 \mathrm{cD}$ & $42.63 \mathrm{cD}$ \\
41 & $1.29 \mathrm{aA}$ & $18.32 \mathrm{~dB}$ & $30.99 \mathrm{bC}$ & $45.18 \mathrm{cD}$ & $54.19 \mathrm{dE}$ \\
48 & $1.68 \mathrm{aA}$ & $20.51 \mathrm{~dB}$ & $32.76 \mathrm{dC}$ & $47.49 \mathrm{dD}$ & $61.16 \mathrm{eE}$ \\
55 & $1.69 \mathrm{aA}$ & $21.63 \mathrm{~dB}$ & $34.28 \mathrm{dC}$ & $50.09 \mathrm{dD}$ & $74.37 \mathrm{fE}$ \\
62 & $1.83 \mathrm{aA}$ & $22.18 \mathrm{~dB}$ & $35.27 \mathrm{dC}$ & $51.57 \mathrm{dD}$ & $80.40 \mathrm{fE}$ \\
\hline
\end{tabular}

"Means followed by the same letter in the column and capital in the row belong to the same group by the Scott-Knott test at $5 \%$ probability.

Based on the average behavior of the CABMV symptoms within and between groups, it is possible to determine when the disease most severely affected each group (Table 3). G1 was most affected at $27 \mathrm{DAI}$, since after this interval the disease did not significantly progress. The MR group reacted most to CABMV up to $41 \mathrm{DAI}$, because after this time, the disease progressed slowly, in accordance with the progress of symptoms. Moreover, the reaction and selection of genotypes belonging to the MS and $\mathrm{S}$ groups can be inferred at $48 \mathrm{DAI}$, considering that after this time there was no significant difference in disease severity at 55 or 62 DAI. The reaction in G5 was classified as HS, since the severity of CABMV evolved until 55 DAI. This result shows that when screening genotypes whose reaction to CABMV has not been previously described, it is prudent to extend the assessment to that time, or consider a minimum severity for classification of the genotypes as susceptible to CABMV.

The results obtained in this study are useful for passionfruit breeding programs because subsequent phenotyping and selections of germplasm bank accessions can be better conducted based on prior knowledge of the temporal dynamics of CABMV disease in different species of Passiflora. Knowledge of the amount of time it takes the disease to become established and its maximum severity after inoculation will assist in the 
adoption of control measures to reduce the damage caused by this pathogen.

\section{CONCLUSIONS}

The mean severity of symptoms caused by CABMV in the $\mathrm{R}, \mathrm{MR}, \mathrm{MS}$ and $\mathrm{S}$ groups can be measured efficiently up to 27,41 and 48 days after inoculation of genotypes. When one does not know the level of resistance of Passiflora genotypes to be evaluated for CABMV, it is recommended to extend the evaluation to the maximum established or consider a minimum severity rating of genotypes that are susceptible $(\mathrm{S})$ to the pathogen.

The evolution of severity of CABMV is dependent on the genetic resistance level of each genotype, but regardless of the group, the evaluation of the CABMV reaction in passionfruit genotypes can be measured efficiently at 55 days after plant inoculation.

The five phenotypic classes established to classify the reaction of different species of passionfruit effectively represent the temporal progress of CABMV disease.

\section{ACKNOWLEDGMENTS}

We gratefully acknowledge the financial support received from the Foundation of Support for Research of the State of Bahia (FAPESB), and scholarship support from Coordination for the Improvement of High Education Personnel (CAPES - Z.S.G. and R.P.D.), and National Council for Scientific and Technological Development (CNPq T.L.S - DCR 0013/2015). E.J.O. receives CNPq research productivity fellowship.

RESUMO: O endurecimento dos frutos causada pelo Cowpea aphid borne mosaic virus (CABMV) é considerada a doença mais importante economicamente limitando a produção de maracujazeiro em vários países. $\mathrm{O}$ objetivo deste trabalho foi avaliar o progresso dos sintomas causados pelo CABMV em espécies de Passiflora. O estudo foi realizado em delineamento em blocos casualizados, em esquema fatorial (80 genótipos x 7 períodos de avaliação) considerando cada planta como uma repetição, utilizando 80 genótipos pertencente a 12 espécies de maracujazeiro. A severidade foi estimada por meio do índice de doença (ID). As avaliações foram realizadas 20, 27, 34, 41, 48, 55 e 62 dias após a inoculação (DAI). As médias do ID foram utilizadas para verificar a evolução da doença em cada período de avaliação. O período mínimo para estabilização do progresso do CABMV foi utilizado para agrupar os genótipos pelo teste Scott-Knott $(\mathrm{p} \leq 0,05)$, bem como para classificar os genótipos em resistente $(\mathrm{R})$, moderadamente resistente (MR), moderadamente suscetível (MS), suscetível (S), e altamente suscetível (AS). A severidade média da doença aumentou gradativamente nos intervalos de 20 a 55 DAI e atingiu seu máximo aos 62 DAI. Cerca de 19, 24, 36, 10 e $11 \%$ do germoplasma avaliado foi classificado como R, MR, MS, S e AS, respectivamente. O progresso temporal da doença foi bastante variável dentro e entre os grupos, embora não tenha sido observada diferença no ID dos genótipos a partir de 55 DAI, indicando a estabilização dos sintomas a partir deste período, independentemente do nível de resistência do genótipo.

PALAVRAS-CHAVE: Passifloracea. Dinâmica temporal. Progresso da doença. Virose.

\section{REFERENCES}

ADAMS, M. J.; ZERBINI, F. M.; FRENCH, R.; RABENSTEIN, F.; STENGER, D. C.; VALKONEN, J. P. T. Family Potyviridae. In: KING, A. M. Q.; ADAMS, M. J.; CARSTENS, E. B.; LEFKOWITZ, E. J. (Ed.). Virus Taxonomy. $9^{\text {th }}$ Report of the International Committee on Taxonomy of Viruses. London, UK: Elsevier Academic Press, 2012. p. 1069-1089.

BARROS, D. R.; ALFENAS-ZERBINI, P.; BESERRA Jr., J. E. A.; ANTUNES, T. F. S.; ZERBINI, F. M. Comparative analysis of the genomes of two isolates of Cowpea aphid borne mosaic virus (CABMV) obtained from different hosts. Archives of Virology, Wien, v. 156, n. 6, p. 1085-1091, 2011. https://doi.org/10.1007/s00705-011-0962-7

BOON, J. A.; DIAZ, A.; AHLQUIST, P. Cytoplasmic viral replication complexes. Cell Host \& Microbe, Cambridge, v. 8, n. 1, p. 77-85, 2010. https://doi.org/10.1016/j.chom.2010.06.010 
BRAGARD, C.; CACIAGLI, P.; LEMAIRE, O.; LOPEZ-MOYA, J. J.; MACFARLANE, S.; PETERS, D.; SUSI, P.; TORRANCE, L. Status and prospects of plant virus control through interference with vector transmission. Annual Review of Phytopathology, Palo Alto, v. 51, p. 177-201, 2013 https://doi.10.1146/annurev-phyto-082712-102346

CERQUEIRA-SILVA, C. B. M.; MELO, J. R. F.; CORRÊA, R. X.; OLIVEIRA, A .C. A history of passion fruit woodiness disease with emphasis on the current situation in Brazil and prospects for Brazilian passion fruit cultivation. European Journal of Plant Pathology, Dordrecht, v. 139, n. 2, p. 261-270, 2014.

https://doi.org/10.1007/s10658-014-0391-z

CERQUEIRA-SILVA, C. B. M.; MOREIRA, C. N.; FIGUEIRA, A. R.; CORRÊA, R. X.; OLIVEIRA, A. C. Detection of a resistance gradient to Passion fruit woodiness virus and selection of 'yellow' passion fruit plants under field conditions. Genetics and Molecular Research, Ribeirão Preto, v. 7, n. 4, p. 1209-1216, 2008. https://doi.org/10.4238/vol7-4gmr484

CHRISTENSEN, N. M.; FAULKNER, C.; OPARKA, K. Evidence for unidirectional flow through plasmodesmata. Plant Physiology, Chicago, v.150, n. 1, p. 96-104, 2009. https://doi.org/10.1104

CORREA, M. F.; PINTO, A. P. C.; REZENDE, J. A. M.; HARAKAVA, R.; MENDES, B. M. J. Genetic transformation of sweet passion fruit (Passiflora alata) and reactions of the transgenic plants to Cowpea aphid borne mosaic virus. European Journal of Plant Pathology, Dordrecht, v. 143, n. 4, p. 813-821, 2015. https://doi.org/10.1007/s10658-015-0733-5

DOLNIK, O.; STEVERMANN, L.; KOLESNIKOVA, L.; BECKER, S. Marburg virus inclusions: A virusinduced microcompartment and interface to multivesicular bodies and the late endosomal compartment. European Journal of Cell Biology, Stuttgart, v. 94, n. 7, p. 323-331, 2015. https://doi.org org/10.1016/j.ejcb.2015.05.006

FERREIRA, S. S.; BARROS, D. R.; ALMEIDA, M. R.; ZERBINI, F. M. Characterization of Passionfruit severe leaf distortion virus, a novel begomovirus infecting passionfruit in Brazil, reveals a close relationship with tomato-infecting begomoviruses. Plant Pathology, Oxford, v. 59, n. 2, p. 221-230, 2010. https://doi.org/10.1111/j.1365-3059.2009.02205.x

FISCHER, I. H.; RESENDE, J. A. M. Diseases of passion flower (Passiflora spp.). Pest Technology, Isleworth, v. 2, n. 1, p. 1-19, 2008.

FREITAS, J. C.; VIANA, A. P.; SANTOS, E. A.; SILVA, F. H.; PAIVA, C. L.; RODRIGUES, R.; EIRAS, M. Genetic basis of the resistance of a passion fruit segregant population to Cowpea aphid borne mosaic virus (CABMV). Tropical Plant Pathology, Brasília, v. 40, n. 5, p. 291-297, 2015. https://doi.org/10.1007/s40858015-0048-2

GARCÊZ, R. M.; CHAVES, A. L. R.; EIRAS, M.; MELETTI, L. M. M.; AZEVEDO FILHO, J. A.; SILVA, L. A.; COLARICCIO, A. Survey of aphid population in a yellow passion fruit crop and its relationship on the spread Cowpea aphid borne mosaic virus in a subtropical region of Brazil. SpringerPlus, Heidelberg, v. 4, n. 537, p. 1-12, 2015. https://doi.org/10.1186/s40064-015-1263-5

HA, C.; COOMBS, S.; REVILL, P. A.; HARDING, R. M.; VU, M.; DALE, J. L. Design and application of two novel degenerate primer pairs for the detection and complete genomic characterization of potyviruses. Archives of Virology, Wien, v. 153, n. 1, p. 25-36, 2008. https://doi.org/10.1007/s00705-007-1053-7

LEÃO, R. M. K.; PEIXOTO, J. R.; JUNQUEIRA, N. T. V.; RESENDE, R. O.; MATTOS, J. K. A.; MELO, B. Reação de progênies de maracujazeiro azedo ao vírus do endurecimento do fruto (Cowpea aphid borne mosaic virus - CABMV) em casa de vegetação. Bioscience Journal, Uberlândia, v. 22, n. 3, p. 87-92, 2006. 
LIMA, J. A. A.; MASCIMENTO, A. K. Q.; BARBOSA, G. S.; GONÇALVES, M. F. B.; MAIA, L. M.; SILVA, F. R. Etiologia, sintomatologia, distribuição geográfica e estratégias de controle de viroses em culturais tropicais. In: LIMA, J. A. A. (Ed.). Virologia essencial \& viroses em culturas tropicais. Fortaleza: Edições UFC, 2015. p. 303-527.

MACIEL, S. C.; NAKANO, D. H.; REZENDE, J. A. M.; VIEIRA, M. L. C. Screening of Passiflora species for reaction to Cowpea aphid-borne mosaic virus reveals an immune wild species. Scientia Agricola, Piracicaba, v. 66, n. 3, p. 414-418, 2009. https://doi.org/10.1590/S0103-90162009000300018

MANDADI, K. K.; SCHOLTHOF, K-B, G. Plant immune responses against viruses: how does a virus cause disease? Plant Cell, Rockville, v.25, n.5, p. 1489-1505, 2013. https://doi.org/10.1105/tpc.113.111658

MCKINNEY, H. H. Influence of soil temperature and moisture on infection of wheat seedlings by Helminthosporium sativum. Journal Agricultural Research, Washington, v. 26, n. 5, p. 195-218, 1923.

MELO, J. R. F.; FIGUEIRA, A. R.; MOREIRA, C. N.; OLIVEIRA, A. C. Recent characterization of Cowpea aphid borne mosaic virus (CABMV) in Bahia State, Brazil, suggests potential regional isolation. African Journal of Biotechnology, Nairobi, v. 14, n. 9, p. 735-744, 2015. https://doi.org/105897/AJB2015.14409

MOWAT, W.P.; DAWSON, S. Detection of plant viruses by ELISA using crude sap extracts and unfractionated antisera. Journal of Virological Methods, Amsterdam, v. 15, n. 3., p. 233-247, 1987. https://doi.org/10.1016/0166-0934(87)90101-7

NETHERTON, C. L.; WILEMAN, T. Virus factories, double membrane vesicles and viroplasm generated in animal cells. Current opinion in virology, Amsterdam, v. 1, n. 5, p. 381-387, 2011.

https://doi.org/10.1016/j.coviro.2011.09.008

NICOLINI, C.; FILHO, F. A. C. R.; RESENDE, R. O.; ANDRADE, G. P.; KITAJIMA, E. W.; PIO-RIBEIRO, G.; NAGATA, T. Possible host adaptation as an evolution factor of Cowpea aphid borne mosaic virus deduced by coat protein gene analysis. Journal of Phytopathology, Berlin, v. 160, n. 2, p. 82-87, 2012. https://doi.org/10.1111/j.1439-0434.2011.01861.x

NOVAES, Q. S.; REZENDE, J. A. M. Selected mild strains of Passion fruit woodiness virus (PWV) fail to protect pre-immunized vines in Brazil. Scientia Agricola, Piracicaba, v. 60, n. 4, p. 699-708, 2003. https://doi.org/10.1590/S0103-90162003000400014

OLIVEIRA, E. J.; SOARES, T. L.; BARBOSA, C. J.; SANTOS-FILHO, H. P.; JESUS, O. N. Severidade de doenças em maracujazeiro para identificação de fontes de resistência em condições de campo. Revista Brasileira de Fruticultura, Jaboticabal, v. 35, n. 2, p. 485-492, 2013. https://doi.org/10.1590/S010029452013000200018

PINTO, P. H. D.; PEIXOTO, J. R.; JUNQUEIRA, N. T. V.; RESENDE, R. D. O.; MATTOS, J. K. D. A.; MELO, B. D. Reação de genótipos de maracujazeiro-azedo ao vírus do endurecimento do fruto (Cowpea aphidborne mosaic virus - CABMV). Bioscience Journal, Uberlândia, v. 24, n. 2, p. 19-26, 2008.

R DEVELOPMENT CORE TEAM. R: A language and environment for statistical computing, Vienna: R Foundation for Statistical Computing, 2015. Available in: <https://cran.r-project.org/>. Access in: August, 15, 2015.

SANTOS, E. A.; VIANA, A. P.; FREITAS, J. C. O.; SILVA, F. H. L.; RODRIGUES, R.; EIRAS, M. Resistance to Cowpea aphid borne mosaic virus in species and hybrids of Passiflora: advances for the control of the passion fruit woodiness disease in Brazil. European Journal of Plant Pathology, Dordrecht, v. 143, n. 1, p. 85-98, 2015. https://doi.org/10.1007/s10658-015-0667-y 
VIANA, C. A. S.; PIRES, M. C.; PEIXOTO, J. R.; JUNQUEIRA, N. T. V.; BLUM, L. E. B. Resistência parcial de genótipos de maracujá-azedo à virose do endurecimento do fruto (Cowpea aphid borne mosaic virus - CABMV). Bioscience Journal, Uberlândia, v. 30, n. 3, p. 338-345, 2014.

VIDA, J. B.; ZAMBOLIM, L.; TESSMANN, D. J.; BRAMDÃO FILHO, J. U. T.; VERZIGNASSI, J. R.; CAIXETA, M. P. Manejo de Doenças de Plantas em Cultivo Protegido. Fitopatologia Brasileira, Brasília, v. 29, n. 4, p. 355-372, 2004. https://doi.org/10.1590/S0100-41582004000400001 